\title{
Utilization of Volcanic Ash and Magnetite Mineral for Peanut Crop Production
}

\author{
Abdel Wahab M. Mahmoud \\ Plant Physiology Division, Agricultural Botany Department, Faculty of Agriculture, Cairo \\ University, Giza, Egypt \\ Abeer A. Mahmoud \\ Plant Physiology Division, Agricultural Botany Department, Faculty of Agriculture, Cairo \\ University, Giza, Egypt \\ Ahmed E. Ghoniem \\ Agricultural Botany Department, Faculty of Agriculture, Cairo University, Giza, Egypt
}

Received: April 21, 2019 Accepted: May 4, $2019 \quad$ Published: May 9, 2019

doi:10.5296/jas.v7i2.14764 URL: https://doi.org/10.5296/jas.v7i2.14764

\begin{abstract}
A field experiment was carried out on sandy soil at Ismailia Governorate during two consecutive seasons of 2017-2018 under dripping irrigation system to study the effect of applied volcanic ash and magnetite mineral alone or mixture compared to recommended fertilizers (chemical fertilizers) as control on soil properties, peanut yield and its quality.

The obtained results show that soil salinity, $\mathrm{pH}$ and soil bulk density were decreased in volcanic ash, magnetite mineral and volcanic ash + magnetite mineral combined treatments, as compared to the control one. The total porosity and water holding capacity (WHC) values were augmented when soil treated by volcanic ash, magnetite mineral and volcanic ash + magnetite mineral, as compared to control. In addition, Hay and pod dry weight were significantly increased with combined treatment 26.40 and $65.00 \%$, respectively over the control treatment. The NPK contents were augmented due to the application of volcanic ash; it also amplified zinc concentration in hay four times and in seed three times that of control treatment. Manganese concentration followed the same trend of $\mathrm{Zn}$ concentration. Iron concentration increased almost five and four times compared with control treatment in hay and seed. Cupper concentration increased by 30 and $70 \%$ in comparison to control treatment in hay and peanut seed, respectively due to volcanic ash application. The highest values of net photosynthesis rate as well as water use efficiency were also obtained from volcanic ash + magnetite mineral combined treatment as compared to those under control plants. The mixture of volcanic ash with magnetite mineral realized the highest oil content and total
\end{abstract}


amino acids. Anatomical studies revealed significant increase in leaf features represented in midrib thickness, length and width of vascular bundle, phloem and xylem tissues and number of xylem vessels in vascular bundle as well as the leaf blade thickness compared to control plants. Combination of volcanic ash with magnetite mineral gave the maximum net profit as compared to control treatment. The agronomic efficiency could be arranged in the following descending order of volcanic ash plus magnetite mineral, > volcanic ash, > magnetite mineral, and finally > control.

Keywords: peanut, chemical constituents, agronomic efficiency, economical evaluation, volcanic ash, magnetite, leaf anatomy

\section{Introduction}

Sandy soils commonly exist in arid and semi-arid regions such Egypt country which they occupy the east and west desert areas. In addition, one of the chief intentions of the agricultural strategy is maximizing land production. The output of sandy soils is usually perimeter by numerous agronomic complications and their inherited inert chemical and biological properties. Such properties originate sandy soil to be infertile with minor production (Ewing and Singer 2012).

Low-cost natural multi-nutrient silicate rock was used as a fertilizer for agricultural production in developing countries (Abou-El-Seoud and Abdel-Megeed 2012). Whole rock silicate fertilizer types have the potential to supply soils by macro and micronutrients depending on soil texture, soil salinity and soil reaction (Van Straaten 2007). Moreover minced silicate rocks are considered as slow release fertilizer for sandy soils. Unfortunately, silicate rocks own low solubility and nutrients availability to plants. So supplying great amounts of minced rock to agricultural land is indeed (Van Straaten 2007). Volcanic rocks can resolve this issue since they considered as soil amendments and could improve the cation exchange capacity of infertile soils. In addition, their nutrient release rate is usually more rapidly than that of silica-rich igneous granite rocks (Chien and Menon 1995). Moreover, young volcanic areas with weathered lavas and ashes are usually believed to be very fertile regions from agricultural point of view.

Magnetite was expressed in forms of oxides as ferrous or ferric. It was reported that magnetite was used as catalyst in industrial synthesis of ammonia. It has many positive effects and application such as pre-sowing seed treatment or irrigation with magnetized water. The plant growth characteristics, root function were improved by magnetic field (Abdul Qadose and Hozayn 2010). It influenced chemical composition of plants and augmented soil nutrients availability, boost yield of different crops and activates plant enzymes such as superoxide dismutase (SOD), catalase (CAT), peroxidase (POX) and ascorbate peroxidase (APX), (Alikamanoglu and Sen 2011).

Peanut (Arachis hypogaea) is one of the most edible crops cultivated in sandy soil areas of Egypt. It is also famous as a king of oil seed (Sathya et al. 2013). Groundnut also has value as a rotation crop with root nodules; it can fix atmospheric nitrogen and therefore improve soil fertility. Generally, the farmer applied recommended doses of chemical fertilizers beside organic sources 
(particularly in sandy soils) in order to boost their yield per unit area (Das 2007).

The current research aims to study the effect of applied volcanic ash and magnetite mineral alone or mixture on soil properties, peanut yield and its quality compared to traditional fertilization.

\section{Material and Methods}

The current work was carried out in a private farm (sandy soil) at Ismailia Governorate (150 $\mathrm{km}$ east Cairo city, Egypt) in order to test the effect of applied volcanic ash or magnetite mineral individual or in combination on some soil properties and peanut crop chemical constituents and yield production. Magnetite mineral was obtained from Alahram Company for mining, Egypt. Volcanic ash was obtained from volcanic mountains in Bandung province, Indonesia. The samples of Magnetite mineral and volcanic ash were air dried, crushed and sieved at Faculty of Engineering, Cairo University. The chemical and physical properties of volcanic ash were carried out according to (Page et al. 1982) and (Klut 1986) as they are presented in table (1). In February 2017, 5 ton/ fed of compost (farmyard manure) was thoroughly mixed with soil surface layer $(30 \mathrm{~cm}$ depth) of the experimental field. The chemical composition of applied compost is shown in Table (2).

Table 1. Some physical and chemical properties of volcanic ash

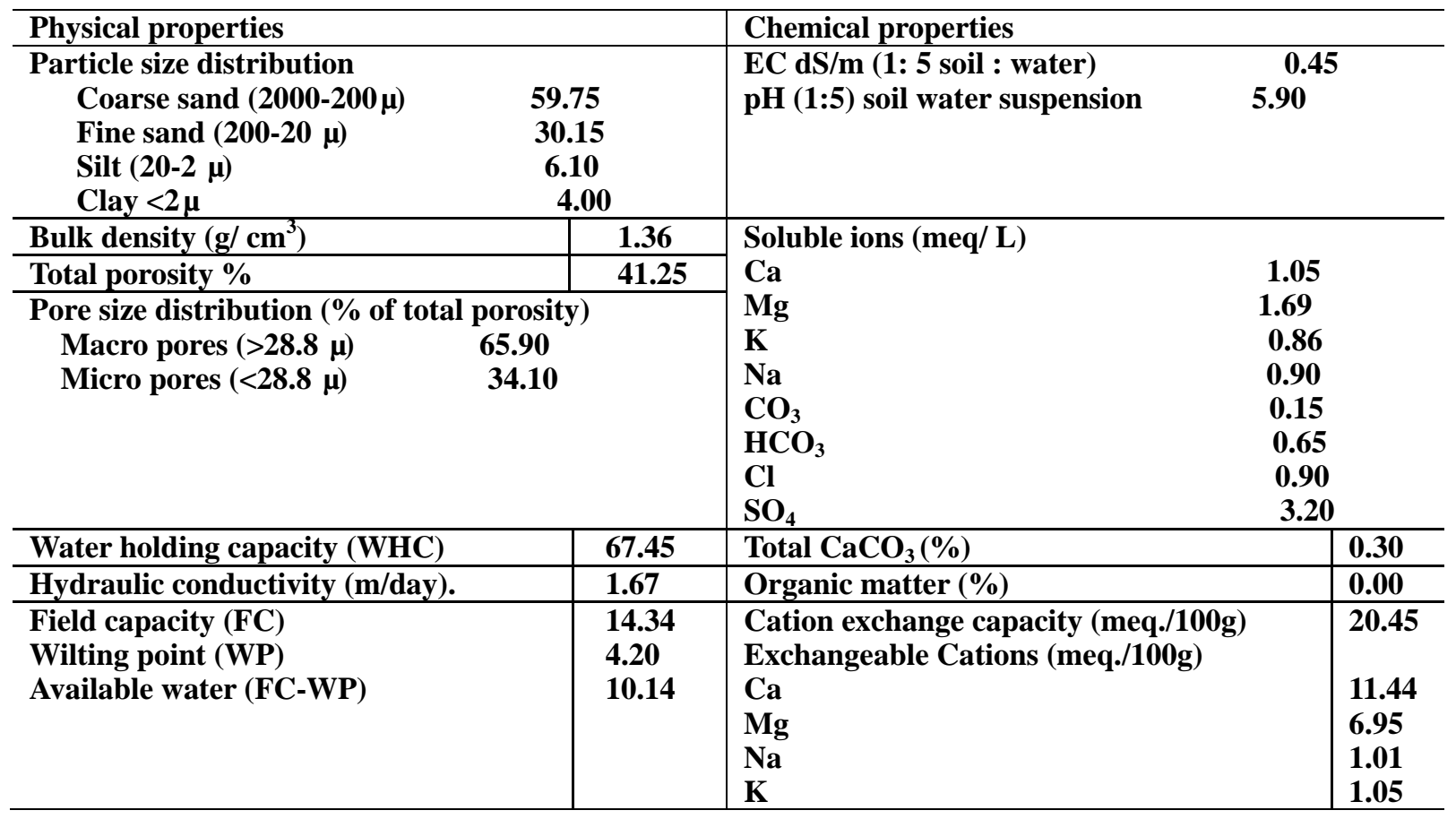




\section{Macrothink}

Table (2). The chemical composition of the applied farmyard manure*

\begin{tabular}{|c|c|}
\hline Property & Value \\
\hline PH $(1: 5)$ & 7.86 \\
\hline EC (1: 5 extract) $[\mathrm{dS} / \mathrm{m}]$ & $\mathbf{3 . 5 8}$ \\
\hline Organic matter [\%] & 55.69 \\
\hline Total-N [\%] & 2.05 \\
\hline Total-K [\%] & 1.46 \\
\hline Total-P [\%] & 1.30 \\
\hline C/N ratio & 14:1 \\
\hline Fe-[ppm] & 208 \\
\hline Mn-[ppm] & 131 \\
\hline $\mathrm{Cu}-[\mathrm{ppm}]$ & 115.00 \\
\hline Zn-[ppm] & 218.00 \\
\hline $\mathrm{N}^{-N_{H}}{ }_{4}^{+}[\mathrm{ppm}]$ & 287.00 \\
\hline $\mathrm{N}-\mathrm{NO}_{3}^{-}[\mathrm{ppm}]$ & 36.45 \\
\hline Ashes [\%] & 32.00 \\
\hline Total content of Bacteria & $2.5 \times 10^{7}$ \\
\hline Total content of Fungi & $7 \times 10^{5}$ \\
\hline Weed seeds & 0.00 \\
\hline Nematode & 0.00 \\
\hline Phosphate dissolving Bacteria & $2.5 \times 10^{6}$ \\
\hline Dehydrogenase activity [mg TPF/100g] & 30.50 \\
\hline Nitrogenous activity [N mol $\mathrm{C}_{2} \mathrm{H}_{4} / \mathrm{g} / \mathrm{hr}$ ] & 120.25 \\
\hline
\end{tabular}

The experiment was laid out in a randomized complete block design with three replicates. The plot area was $200 \mathrm{~m}^{2}$ (20 m length $\mathrm{x} 10 \mathrm{~m}$ width). The experiment treatments were as follows:

1) Control treatment received a recommended dose of NPK in form of ammonium sulphate $(20 \% \mathrm{~N})$, calcium superphosphate $\left(15.5 \% \mathrm{P}_{2} \mathrm{O}_{5}\right)$ and potassium sulphate $\left(48 \% \mathrm{~K}_{2} \mathrm{O}\right)$ at rates of 100,200 and $50 \mathrm{~kg} /$ fed., respectively. Calcium superphosphate was added during soil preparation. The amount of ammonium sulphate was divided into two equal doses; the first one was applied 30 days after planting and the second was applied 60 days after planting. The amount of potassium sulphate divided into two doses and they added at the same time of ammonium sulphate application.

2) Volcanic ash treatment got $30 \mathrm{~kg}$ volcanic ash/ plot mixed well with $30 \mathrm{~cm}$ soil surface.

3) Magnetite mineral treatment received $15 \mathrm{~kg}$ magnetite mineral/ plot mixed well with 30 $\mathrm{cm}$ soil surface.

4) Volcanic ash and magnetite mineral treatment got $30 \mathrm{~kg}$ volcanic ash $+15 \mathrm{~kg}$ magnetite mineral/ plot mixed well with $30 \mathrm{~cm}$ soil surface.

Peanut seeds (Arachis hypogaea, Giza 5) were planted on 13 $3^{\text {th }}$ April, 2017 (25 kg/fed) at 60 $\mathrm{cm}$ away among rows and $20 \mathrm{~cm}$ space between seed (each plot has 15 rows) and they irrigated by sprinkler irrigation system. The plants were harvested 125 days after planting for the first season. The second season on $15^{\text {th }}$ April 2018 peanut seeds were planted under same both place and conditions then harvested after 120 days. Plants of each plot were cropped, air dried and the yield and yield traits were recorded. Total nitrogen content of the dried leaves was determined according to the method described by (Helrich 1990). The nitrogen percentage was multiplied by 6.25 to get the crude protein percentages. Phosphorus 
was determined calorimetrically according to (Jackson 1973). Potassium concentration was determined using flame photometer according to (Jackson 1973). Zinc, manganese, iron and copper content were determined using Atomic Absorption Spectrophotometer according to (Page et al. 1982). Total carbohydrates percent in seeds were determined according to the method described by (Helrich 1990). Net photosynthesis on an area basis ( $\mu$ mol $\mathrm{CO}_{2} \mathrm{~m}^{-}{ }^{2} \mathrm{~s}^{\mathrm{l}}$ ), leaf stomatal conductance ( $\mathrm{mol} \mathrm{H} 2 \mathrm{O} \mathrm{m}-2 \mathrm{~s}-1$ ), and water use efficiency of five different leaves per treatment were monitored using a LICOR 6400 (Lincoln, Nebraska, USA) infrared gas analyzer (IRGA). The oil was extracted from seeds using a Soxhlet apparatus according to (Kinsella et al. 1977). Free amino acids contents in maturing seeds were determined according to the method described by (Young et al. 1974).

After harvesting season, envoy disturbed and undisturbed soil samples $(0-40 \mathrm{~cm})$ were subjected for some chemical and hydro-physical analysis. Particle size distribution, soil salinity, soil reaction and soluble ions, were determined according to (Page et al. 1982). Soil bulk density was verified by core method and total soil porosity was computed using the data of bulk density according to (Kulte 1986). Soil moisture characteristics were carried out using the pressure cooker apparatus according to (Kulte 1986). Available water and Pore size distribution was calculated from the soils moisture retention curve and classified according to (De-Leenheer and De-Boodt 1965). Saturated hydraulic conductivity was measured in undisturbed soil cores using the constant head method according to (Kulte 1986).

*Anatomical studies

At the end of each season (first and second), specimens of leaves were taken and fixed for at least 48 hours in F.A.A. solution (5ml. formalin, 5ml. glacial acetic acid and $90 \mathrm{ml}$. ethyl alchohol 70\%), washed in $50 \%$ ethyl alcohol, dehydrated in a series of ethyl alcohols $(70,90$, 95 and 100\%), infiltrated in xylene, embedded in paraffin wax of a melting point 60-63 0C (Nassar and El-Sahhar 1998). sectioned to 20 microns in thickness using a rotary microtome, double stained with fast green and safranin, cleared in xylene and mounted in Canada balsam (Willey 1971). Sections were microscopically examined using a micrometer eye piece read to detect histological manifestation of noticeable responses resulted from treatments. Averages of readings from 4 slides / treatment were calculated.

\section{*Economic evaluation}

The yield components were calculated and economic analysis was performed using the following equations proposed by (FAO 2000), (Sarwar, et al. 2007) and (Mubashir, et al. 2010).
Gross income
$=$ yield $\times$ price
Profitable return [PR]
$=$ gross income - total production cost
$\mathrm{PR} \%$ over control $\quad=\mathrm{PR}-$ control treatments
Benefit cost ratio $[\mathrm{BCR}]=\mathrm{PR}$ over control $/$ total production cost
Investment factor $[\mathrm{IF}]=$ gross income $/$ total production cost 


\section{Results and Discussion}

\section{* Soil chemical properties}

Soil salinity data as electrical conductivity [EC] are presented in Table (3). In general, the data show that soil salinity is quite decreased by volcanic ash or magnetite mineral application. It decreased by $14.5,6.9$ and $24.1 \%$ in volcanic ash, magnetite mineral and volcanic ash + magnetite mineral treatments, respectively compared to the control one. This might be attributed to that the used materials serve as hydrophilic soil conditioner that absorb more water that mitigate the hazardous effect of soil salinity (Bartels 2005). Also, volcanic ash contained anhydrite mineral which can reduce salinity level in sandy soil.

Table (3). Soil chemical properties as influenced by volcanic ash and magnetite mineral application

\begin{tabular}{|c|c|c|c|c|c|c|c|c|c|}
\hline \multirow{2}{*}{ Treatment } & \multirow[t]{2}{*}{ pH } & \multirow{2}{*}{$\begin{array}{l}\text { EC } \\
{[\mathrm{dS} / \mathrm{m}]}\end{array}$} & \multicolumn{7}{|c|}{ Soluble ions [meq/l] } \\
\hline & & & $\mathrm{Ca}^{2+}$ & $\mathrm{Mg}^{2+}$ & $\mathbf{K}^{+}$ & $\mathbf{N a}^{+}$ & $\mathrm{HCO}_{3}^{-}$ & $\mathrm{CL}^{-}$ & $\mathrm{SO}_{4}^{2-}$ \\
\hline Control & 8.75 & 1.45 & 6.40 & 4.58 & 0.07 & 3.64 & 1.99 & 4.85 & 7.85 \\
\hline Volcanic ash & 7.71 & 1.24 & 3.30 & 2.37 & 0.35 & 8.84 & 2.59 & 3.82 & 8.59 \\
\hline Magnetite mineral & 7.78 & 1.35 & 3.15 & 4.10 & 0.51 & 6.00 & 1.99 & 4.85 & 6.86 \\
\hline $\begin{array}{l}\text { Volcanic ash+ } \\
\text { Magnetite mineral }\end{array}$ & 7.65 & 1.10 & 3.23 & 1.14 & $\mathbf{0 . 5 3}$ & 6.10 & 2.64 & 4.37 & 3.99 \\
\hline
\end{tabular}

Soil reaction $[\mathrm{pH}]$ is one of the most important parameters which reflect the overall change in soil chemical properties. Data in Table (3) revealed that the $\mathrm{pH}$ values varied from 8.75 to 7.65 which are considered alkaline. In general $\mathrm{pH}$ values decreased by $11.9,11.1$ and $12.6 \%$ in volcanic ash, magnetite mineral and volcanic ash + magnetite mineral treatments, respectively compared to the control one. This might be due to the low $\mathrm{pH}$ of the applied materials.

\section{* Soil physical properties}

Data in Table (4) revealed that the soil texture is sandy since the sand fraction represented more than $85 \%$ of total soil particles size. In the same context, silt and clay fractions represented about 9 and $6 \%$ of total soil particles size, respectively. The bulk density values were slightly decreased by 4.20, 6.60 and $5.40 \%$ (Table 4) in volcanic ash, magnetite mineral and volcanic ash + magnetite mineral treatments, respectively compared to the control one. In mean while, the total porosity values were augmented by $7.02,4.60$ and $7.30 \%$ (Table 4) in the corresponding treatments. The used materials realized positive effects on soil bulk density and total porosity which reflects an enhancement in water holding properties of sandy soil. The obtained results agreed with those obtained by (Dexter 2004). These results can be 
inspected to the relocation of soil particles, enlargement in bulk soil volume and the binding action of magnetite and volcanic ash individual or in combination moreover the role of compost which assess to improve soil structure, mainly in aggregate formation. These findings are in harmony with those obtained by (Hassan and Abd El-Wahab 2012). who reported that the application of natural minerals had an improving effect on soil bulk density.

Table (4). Some hydro-physical properties as affected by volcanic ash and magnetite mineral application

\begin{tabular}{|c|c|c|c|c|}
\hline \multirow[b]{2}{*}{ Soil properties } & \multicolumn{4}{|c|}{ Treatments } \\
\hline & Control & $\begin{array}{l}\text { Volcani } \\
\text { c ash }\end{array}$ & $\begin{array}{l}\text { Magnetit } \\
\text { e } \\
\text { mineral }\end{array}$ & $\begin{array}{l}\text { Volcanic ash+ } \\
\text { Magnetite } \\
\text { mineral }\end{array}$ \\
\hline Coarse sand [\%] & 69.60 & 68.10 & 66.00 & 67.15 \\
\hline Fine sand [\%] & 16.27 & 17.78 & 21.15 & 20.90 \\
\hline Silt [\%] & 7.29 & 9.22 & 6.65 & 8.95 \\
\hline Clay [\%] & 6.84 & 4.90 & 6.20 & 3.00 \\
\hline Texture class & Sandy & sandy & Sandy & Sandy \\
\hline Bulk density $\quad[\mathrm{g} / \mathrm{cm} 3]$ & 1.67 & 1.60 & 1.56 & 1.58 \\
\hline Total porosity [\%] & 37.0 & 39.85 & 38.75 & 39.89 \\
\hline Water holding capacity[\%] & 20.33 & 23.45 & 25.19 & 27.59 \\
\hline Field capacity[\%] & 7.59 & 13.58 & 11.85 & 14.82 \\
\hline Wilting percentage [\%] & 3.17 & 2.85 & 2.15 & 3.42 \\
\hline Available water[\%] & 4.42 & 10.73 & 9.70 & 11.40 \\
\hline $\begin{array}{l}\text { Hydraulic conductivity } \\
{[\mathrm{cm} / \mathrm{h}]}\end{array}$ & 6.25 & 3.58 & 3.75 & 3.18 \\
\hline
\end{tabular}

\section{* Growth traits}

The effect of volcanic ash or/ and magnetite mineral application on hay, pod yields and 100 seed weight of peanut were recorded in Table (5). Data confirmed that the average values of 
both seasons (2017-2018) of hay and pod dry weight were increased from 2.14 and 3.06 ton/ hectare in the control treatment to 2.88 and $8.74 \mathrm{ton} /$ hectare for the combined treatments (volcanic ash and magnetite mineral), respectively, representing $26.40 \%$ and $65.00 \%$ over the control treatment, respectively.

Table (5). Effect of volcanic ash or/ and magnetite mineral application on hay, pod and 100 seed weight of peanut crop

\begin{tabular}{l|l|l|l}
\hline Treatment & $\begin{array}{l}\text { Hay }[\mathrm{Kg} / \\
\text { h] }\end{array}$ & Pod $[\mathrm{Kg} / \mathrm{h}]$ & $\begin{array}{l}\text { l00 } \\
\text { [g/plant }]\end{array}$ \\
\hline Control & $2139.00^{\mathrm{b}}$ & $3059.00^{\mathrm{c}}$ & $101.80^{\mathrm{c}}$ \\
\hline Volcanic ash & $2415.00^{\mathrm{b}}$ & $\mathbf{5 0 6 0 . 0 0}^{\mathrm{b}}$ & $118.98^{\mathrm{b}}$ \\
\hline Magnetite mineral & $2005.60^{\mathrm{c}}$ & $4634.50^{\mathrm{b}}$ & $115.44^{\mathrm{b}}$ \\
\hline Volcanic ash+ Magnetite mineral & $2875.00^{\mathrm{a}}$ & $\mathbf{8 7 4 0 . 0 0 ^ { \mathrm { a } }}$ & $131.98^{\mathrm{a}}$ \\
\hline
\end{tabular}

The values are average of both seasons (2017 and 2018)

\section{Means with the same letter in a column are not significantly different by DMRT $5 \%$}

Such result coincided with those obtained by (Radhakrishnan and Kumari 2012) Moreover (Aladjadjiyan 2010)stated that magnetite mineral application alone or mixed with volcanic ash increased pod and foliage yield. Concerning the effect of different treatments on 100 seed weight, data revealed that the combination between volcanic ash and magnetite mineral realized a positive effect on 100 seed weight, followed by volcanic ash treatment and magnetite mineral. These results could be elucidated due to the relative high content of minerals inside both volcanic ash and magnetic mineral. The results are in agreement with those obtained by (Fyfe, et al. 1983) that depicted those young volcanic areas with weathered lavas and ashes are usually led to very fertile agricultural regions.

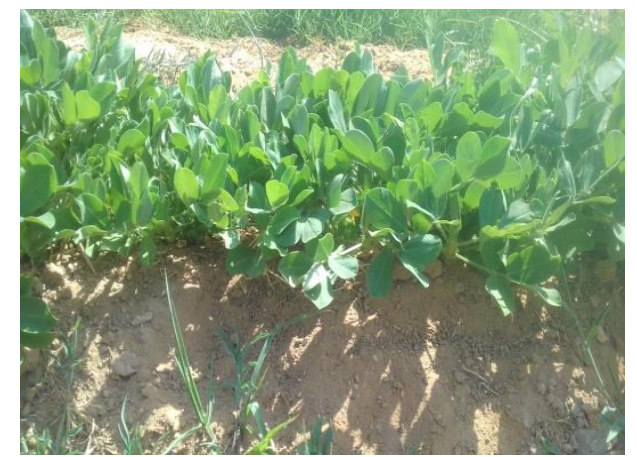

Control

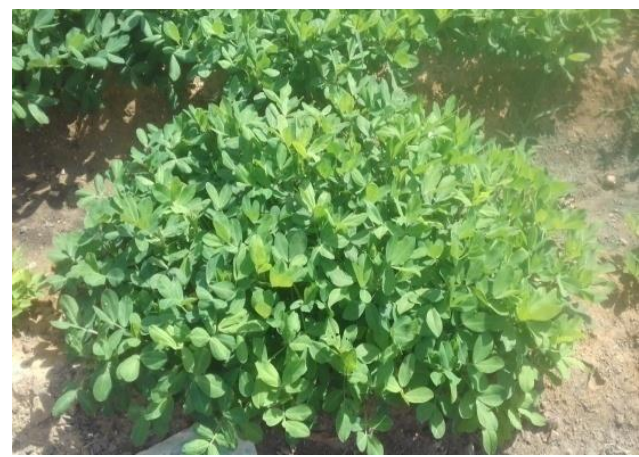

Volcanic ash+ Magnetite mineral

*chlorophyll content, photosynthetic rate and water use efficiency 
It came into sight from data in Table (6) that, appliance of combined treatments (volcanic ash and magnetite mineral) significantly increased total chlorophyll in comparison with control plants where, these increments were $81.5 \%$ over control. Additionally volcanic ash alone recorded significant increment in total chlorophyll $42 \%$ in comparison with control.

Table (6). Effect of volcanic ash or/ and magnetite mineral application on chlorophyll content, photosynthetic rate and water use efficiency

\begin{tabular}{|c|c|c|c|c|}
\hline Treatment & $\begin{array}{l}\text { Total } \\
\text { chlorophylls } \\
{[\mathrm{mg} / \mathrm{g}]}\end{array}$ & $\begin{array}{l}\text { Photosynthetic } \\
\text { rate }[\mu \text { mol } \\
\left.\mathrm{CO}_{2} \mathrm{~m}^{-2} \mathrm{~s}^{-1}\right]\end{array}$ & $\begin{array}{l}\text { Transpiration } \\
\text { rate }[\mathrm{m} \text { mol } \\
\left.\mathrm{H}_{2} \mathrm{O} \mathrm{m}^{-2} \mathrm{~s}^{-1}\right]\end{array}$ & $\begin{array}{l}\text { Water use } \\
\text { efficiency[WUA] }\end{array}$ \\
\hline Control & $1.75^{\mathrm{c}}$ & $21.753^{c} \pm 0.1$ & $2.869^{a}$ & $7.58^{c}$ \\
\hline Volcanic ash & $2.49^{b}$ & $24.682^{b} \pm 0.1$ & $1.771^{b}$ & $13.93^{b}$ \\
\hline Magnetite mineral & $1.72^{\mathrm{c}}$ & $19.533^{d} \pm 0.1$ & $2.592^{\mathrm{a}}$ & $7.53^{c}$ \\
\hline $\begin{array}{l}\text { Volcanic ash+ } \\
\text { Magnetite mineral }\end{array}$ & $3.18^{\mathrm{a}}$ & $27.471^{\mathrm{a}} \pm 0.2$ & $1.374^{b}$ & $20^{a}$ \\
\hline
\end{tabular}

The values are average of both seasons (2017 and 2018)

\section{Means with the same letter in a column are not significantly different by DMRT $5 \%$}

Concerning diurnal mean leaf photosynthesis rate of Arachis hypogaea under different treatments as exposed in Table (6) undeniably reveal that, plants under combined treatment significantly provided higher value of net photosynthesis rate $27.4 \pm 0.2 \mu \mathrm{mol} \mathrm{CO}_{2} \mathrm{~m}^{-2} \mathrm{~s}^{-1}$ compared to those under control plants 21.753 $0.1 \mu \mathrm{mol} \mathrm{CO}_{2} \mathrm{~m}^{-2} \mathrm{~s}^{-1}$. Regardless of treatments, photosynthesis rate values were highest in the 1200 hour and can be attributed to the considerable availability of photosynthetic active radiation throughout the study period. From noon, all photosynthesis rate values declined slightly towards the 1600 hour could be due to either higher evaporative demand or the reduction of photosynthetic active radiation.

Go along with transpiration rate, the data as depicted in Table (6) showed that, the highest significant value of transpiration rate out came from control treatment $2.869 \mathrm{~m} \mathrm{~mol} \mathrm{H}_{2} \mathrm{O} \mathrm{m}^{-2}$ $\mathrm{s}^{-1}$ in comparison with combined treatment (Volcanic ash+ Magnetite mineral) which gave the lowest value mol $\mathrm{H}_{2} \mathrm{O} \mathrm{m}^{-2} \mathrm{~s}^{-1}$. This was due to the impact of stomatal opening which maintained photosynthetic efficiency without much considerable change in water potential under desert condition (Zainudin et al. 2010). The decreased of either photosynthesis rate in other treatments can be attributed to the direct inhibition of biochemical processes through ionic, osmotic or other conditions were induced by loss of cellular water. Some other factor that contributed to this diminish might be the limited CO2 diffusion into the intercellular spaces of the leaf as a consequence of reduced stomatal conductance (Lawlor 2002). Side by side with earlier data, application of volcanic ash mixed with magnetite donated significant 
increment in water use efficiency under desert condition and dripping water system since prior combined gave $20 \mu \mathrm{mol} \mathrm{mmol}{ }^{1}$ compared to control plants $7.58 \mu \mathrm{mol} \mathrm{mmol}^{-1}$, the result may be due to elevation of $\mathrm{Co}_{2}$ and this is beneficial to crops grown in water limited areas (Dong et al. 2004).

Generally crop water use efficiency is an especially important consideration where irrigation water resources are limited or diminishing and where rainfall is a limiting factor as the condition of Egypt reclaimed desert. Moreover one of the components of a management system that affects water use efficiency is soil fertility; consequently a complete fertility represented in combination of compost with zeolite helps to produce a crop with roots that explore more soil volume for water and nutrients in less time. This results in a healthier crop that can more easily withstand seasonal stresses or conditions (Stewart and Shamdasani 1990).

\section{* Hay and seed quality of peanut crop}

Data in Table (6) illustrated that, macro elements N, P and K concentrations in plant organs as mean values of both 2015 and 2016 seasons. The NPK contents were augmented due to the application of volcanic ash. The $\mathrm{N}$ concentration in hay recorded values of $0.084,0.070$ and $0.089 \%$ when soil treated by volcanic ash, magnetite mineral and volcanic ash plus magnetite mineral, respectively. Furthermore, the obtained results proved that $\mathrm{N}$ concentration in hay were increased by 182.82, 135.69 and $199.66 \%$ when soil treated by volcanic ash, magnetite mineral and volcanic ash + magnetite mineral, respectively compared to the untreated one (control). The $\mathrm{N}$ concentration in seed recorded values of $0.027,0.0251$ and $0.035 \%$ when soil treated by volcanic ash, magnetite mineral and volcanic ash plus magnetite mineral, respectively. In addition, the obtained results verified that $\mathrm{N}$ concentration in seed were decreased by $63.17,65.76$ and $52.25 \%$ when soil treated by volcanic ash, magnetite mineral and volcanic ash + magnetite mineral, respectively compared to control. These results were in agreement with those obtained by (Dexter 2004), who stated that the chemical composition of plants was influenced by magnetite mineral compared to the control treatment.

Table (6). Effect of volcanic ash or/ and magnetite mineral on nitrogen, phosphorus and potassium content of hay and seed of peanut crop

\begin{tabular}{|c|c|c|c|c|c|c|}
\hline \multirow{2}{*}{ Treatment } & \multicolumn{3}{|l|}{ Hay } & \multicolumn{3}{|l|}{ Seeds } \\
\hline & $\mathbf{N}[\%]$ & $\mathbf{P}[\%]$ & $\mathbf{K}[\%]$ & $\mathbf{N}[\%]$ & $\mathbf{P}[\%]$ & $\mathbf{K}[\%]$ \\
\hline Control & $0.0297^{\mathrm{c}}$ & $0.016^{c}$ & $0.0198^{c}$ & $\mathbf{0 . 0 2 3 3}^{\mathrm{b}}$ & $0.0214^{c}$ & 0.0122 \\
\hline Volcanic ash & $0.0840^{\mathrm{a}}$ & $0.077^{b}$ & $0.0280^{b}$ & $0.0270^{\mathrm{a}}$ & $0.0365^{\mathrm{a}}$ & $0.0325^{\circ}$ \\
\hline Magnetite mineral & $0.0700^{b}$ & $0.065^{b}$ & $0.0400^{\mathrm{a}}$ & $0.0251^{b}$ & $0.0264^{b}$ & 0.0279 \\
\hline Volcanic ash+ Magnetite mineral & $0.0890^{\mathrm{a}}$ & $0.095^{\mathrm{a}}$ & $0.0600^{\mathrm{a}}$ & $0.0350^{\mathrm{a}}$ & $0.0374^{\mathrm{a}}$ & $\mathbf{0 . 0 3 8 7 ^ { \circ }}$ \\
\hline
\end{tabular}

The values are average of both seasons (2017 and 2018)

Means with the same letter in a column are not significantly different by DMRT 5\% 
The same trend of $\mathrm{N}$ concentration in hay was observed with $\mathrm{P}$ and $\mathrm{K}$ concentrations. The $\mathrm{P}$ contents in hay were increased by $381.25,306.25$ and $493.75 \%$ when soil treated by volcanic ash, magnetite mineral and volcanic ash + magnetite mineral, respectively compared to the untreated one (control). The K contents in hay were increased by 41.41, 102.02 and $203.03 \%$ when soil treated by volcanic ash, magnetite mineral and volcanic ash + magnetite mineral, respectively compared to the untreated one (control). The $\mathrm{P}$ concentration in seed recorded values of $0.0365,0.0264$ and $0.0374 \%$ when soil treated by volcanic ash, magnetite mineral and volcanic ash plus magnetite mineral, respectively. The obtained data confirmed that $\mathrm{P}$ concentration in seed were decreased by 59.89, 70.99 and $58.90 \%$ when soil treated by volcanic ash, magnetite mineral and volcanic ash + magnetite mineral, respectively compared to the untreated one (control). Regarding potassium concentrations in seeds, the concentration of $\mathrm{K}$ increased from $0.0198 \%$ in the control treatment to $0.028,0.040$ and $0.060 \%$ in volcanic ash, magnetite mineral and volcanic ash plus magnetite mineral treatments, respectively. The K concentration was augmented by 140.70, 201.0 and $301.50 \%$ due to the application of volcanic ash, magnetite mineral and volcanic ash plus magnetite mineral, respectively. These findings were in agreement with those obtained by (Leonardosoh and Kronbergbi 1987) and (Harley and Gilkes 2000).

It was observed that the tested micronutrients $(\mathrm{Zn}, \mathrm{Mn}, \mathrm{Fe}$ and $\mathrm{Cu})$ either in hay or in seeds were augmented when soil treated by volcanic ash plus magnetite mineral while they decreased when soil treated by magnetite mineral only Table (7). The application of volcanic ash amplified zinc concentration in hay four times and in seed three times that of control treatment. Manganese concentration followed the same trend of $\mathrm{Zn}$ concentration since it increased three times that of control in both hay and seed peanut crop by volcanic ash application. Iron concentration increased almost five and four times that of control treatment in hay and peanut seed, respectively by volcanic ash application. Cupper concentration increased by 30 and $70 \%$ of that in control treatment in hay and peanut seed, respectively by volcanic ash application Table (7).

Table (7). Effect of volcanic ash and magnetite mineral application on micronutrients content in hay and seed peanut

\begin{tabular}{|c|c|c|c|c|c|c|c|c|}
\hline \multirow[b]{2}{*}{ Treatment } & \multicolumn{4}{|l|}{ Hay } & \multicolumn{4}{|l|}{ Seeds } \\
\hline & $\begin{array}{l}\mathbf{Z n} \\
{[\%]}\end{array}$ & $\begin{array}{l}\text { Mn } \\
{[\%]}\end{array}$ & $\begin{array}{l}\mathbf{F e} \\
{[\%]} \\
\end{array}$ & $\begin{array}{l}\mathrm{Cu} \\
{[\%]}\end{array}$ & $\begin{array}{l}\mathbf{Z n} \\
{[\%]}\end{array}$ & $\begin{array}{l}\text { Mn } \\
{[\%]}\end{array}$ & $\begin{array}{l}\mathrm{Fe} \\
{[\%]}\end{array}$ & $\begin{array}{l}\mathrm{Cu} \\
{[\%]}\end{array}$ \\
\hline & $0.0012^{\mathrm{c}}$ & $0.0023^{\mathrm{c}}$ & $0.0048^{d}$ & $0.0009^{\mathrm{c}}$ & $0.0020^{\mathrm{c}}$ & $0.0024^{\mathrm{c}}$ & $0.0087^{\mathrm{c}}$ & $0.0010^{b}$ \\
\hline Volcanic ash & $\mathbf{0 . 0 0 4 8}^{\mathrm{b}}$ & $\mathbf{0 . 0 0 6 5}^{\mathrm{b}}$ & $\mathbf{0 . 0 2 3 4}^{\mathrm{b}}$ & $\mathbf{0 . 0 0 1 2}^{\mathrm{b}}$ & $\mathbf{0 . 0 0 5 8}^{\mathrm{b}}$ & $0.0061^{b}$ & $0.0290^{b}$ & $0.0017^{\mathrm{a}}$ \\
\hline Magnetite mineral & $0.0006^{\mathrm{d}}$ & $0.0019^{d}$ & $0.0219^{\mathrm{c}}$ & $0.0005^{\mathrm{c}}$ & $0.0007^{d}$ & $0.0021^{\mathrm{c}}$ & $0.0254^{b}$ & $\mathbf{0 . 0 0 0 8}^{\mathrm{b}}$ \\
\hline $\begin{array}{lc}\text { Volcanic ash } & \text { plus } \\
\text { Magnetite } & \text { mineral }\end{array}$ & $0.0059^{\mathrm{a}}$ & $0.0068^{\mathrm{a}}$ & $0.0312^{\mathrm{a}}$ & $0.0016^{\mathrm{a}}$ & $0.0067^{\mathrm{a}}$ & $0.0085^{a}$ & $0.0345^{\mathrm{a}}$ & $0.0023^{a}$ \\
\hline
\end{tabular}

\section{The values are average of both seasons (2017 and 2018)}

\section{Means with the same letter in a column are not significantly different by DMRT 5\%}

The above mentioned results might be revealing the advantageous effect of volcanic ash application on micronutrients concentration in peanut crop. Volcanic ash might encourage the formation of soluble complexes of micronutrients and assist their uptake by plant since it 
could consider as a slow release fertilizer. This result was in harmony with those obtained by (Fyfe et al. 1983) that represented those young volcanic areas with ashes and weathered lavas are generally guided to extremely fertile agricultural lands. On Citrus sp (Bernardi et al. 2008) reported that, using volcanic ash increased dry matter production, leaf area, N, P, K, Fe, Zn, Mn and Chlorophyll levels relative to the control without zeolite. Also, (Iskander et al. 2011) on zinc and manganese behavior mentioned that the available form of $\mathrm{Zn}$ and $\mathrm{Mn}$ concentration for plant uptake increased in the presence of volcanic ash compared to the control.

\section{* Oil content in seeds}

Data in Table (8) illustrated that the oil contents were amplified under all used materials compared to the control one. Among these treatments, the mixture of volcanic ash with magnetite mineral realized high oil content $(42.0 \mathrm{~kg} / \mathrm{fed})$. This may be attributed to the relative high contents of elements inside both volcanic ash and magnetite mineral which positively affected the oil content, and powered the chemical composition of plants and reflect highest oil content of peanut. This result was in agreement with previous study which reported that magnetite mineral, influenced the chemical composition of plants by (Radhakrishnan and Kumari. 2012). The chemical composition of plants were powered augment soil nutrients availability (Mostafzadeh et al. 2011) stimulate plant enzymes (Shabrangi, A., et al. 2011). and boost the yield of maize and soya bean (Zepeda et al. 2011) Meanwhile, magnetite mineral improved plant growth characteristics (Abou El-Yazied et al. 2012; Esitken and Turan 2004)

Table (8). Effect of volcanic ash and magnetite mineral application on oil, protein and carbohydrates contents of peanut crop

\begin{tabular}{l|l|l|l}
\hline \multirow{2}{*}{ Treatments } & \multirow{2}{*}{$\begin{array}{l}\text { Oil content } \\
{[\text { Kg/ fed] }}\end{array}$} & \multicolumn{2}{|c}{ Seeds } \\
\cline { 3 - 4 } & & Protein[\%] & Carbohydrates[\%] \\
\hline Control & $52.90^{\mathrm{b}}$ & $15.00^{\mathrm{b}}$ & $60.80^{\mathrm{a}}$ \\
\hline Volcanic ash & $92.00^{\mathrm{a}}$ & $30.00^{\mathrm{a}}$ & $29.00^{\mathrm{b}}$ \\
\hline Magnetite mineral & $89.70^{\mathrm{a}}$ & $31.00^{\mathrm{a}}$ & $28.00^{\mathrm{b}}$ \\
\hline Volcanic ash plus magnetite mineral & $96.60^{\mathrm{a}}$ & $33.00^{\mathrm{a}}$ & $24.00^{\mathrm{b}}$ \\
\hline
\end{tabular}

The values are average of both seasons (2017 and 2018)

\section{Means with the same letter in a column are not significantly different by DMRT 5\%}

Regarding protein content in peanut seeds, data in Table (8) confirmed that applied materials alone or in mixture were altered the protein content in seed two fold than in the control treatment. The carbohydrates content in peanut seeds were decreased by volcanic ash or/ and 
magnetite mineral application. Under volcanic ash or/ and magnetite mineral treatments, the carbohydrates content were one third that in control treatment Table (8). This relative decrease may be accounted on the relative high contents of oil and protein in peanut seeds.

\section{* Total amino acids}

In comparison with control plants which provided $54.85 \mathrm{mg}$ total amino acids/ $\mathrm{g}$ identified peanut seed, the data represented in Table (9) demonstrated that total amino acids realized a value of 57.77, 55.20 and $64.02 \mathrm{mg} / \mathrm{g}$ peanut seed when the soil treated by volcanic ash, magnetite mineral and volcanic ash plus magnetite mineral, respectively. The total amino acids increased by 5.32, 0.64 and $16.72 \%$ for the corresponding treatments. The augmentation of essential oil yield with treatment of volcanic ash \& Magnetite mineral could be elucidate on the sources of available elements, that lead to boost in biochemical processes inside the plant (extra of metabolism) hence an increase in essential oil content. The results were in harmony with those obtained by (Gayathiri and Anburani 2008). on kacholam Kaempferia galanga who stated that application of humic substances alone or in combination with other nutrients increased oil content. Furthermore, (Gholizadeh et al. 2006) on Moldavian balm (Dracocephalum moldavica L.) reported that, the highest essential oil content was recorded for $25 \mathrm{~g}$ zeolite/kg. (Abd-El-Latif 2006). on Salvia officinalis plants reported that, the application of $\mathrm{N}$ at $300 \mathrm{~kg}, \mathrm{P}_{2} \mathrm{O}_{5}$ at $200 \mathrm{~kg}$ and $\mathrm{K}_{2} \mathrm{O}$ at $100 \mathrm{~kg} / \mathrm{fed}$ significantly increased the essential oil percentage, the essential oil yield and $\alpha$-pinene, $\beta$-pinene, 1, 8 cineole, thujone and carvacrol percentages in the oil over control plants. (Amber et al. 2008) on Ocimum basilicum plants, obtained the best results in term of essential oil content with application of $\mathrm{N}$ at 75 and $100 \mathrm{~kg} \mathrm{~N} / \mathrm{ha}$.

Table (9). Total amino acids compositions as affected by volcanic ash or/ and magnetite mineral applications

\begin{tabular}{|c|c|c|c|c|}
\hline \multirow{2}{*}{$\begin{array}{l}\text { Amino acids } \\
{[\mathrm{mg} / \mathrm{g}] \text { peanut }}\end{array}$} & \multicolumn{4}{|c|}{ Treatments } \\
\hline & Control & $\begin{array}{l}\text { Volcanic } \\
\text { ash }\end{array}$ & $\begin{array}{l}\text { Magnetite } \\
\text { mineral }\end{array}$ & $\begin{array}{l}\text { Volcanic ash plus } \\
\text { magnetite mineral }\end{array}$ \\
\hline Glutamate & 2.38 & 2.66 & 1.09 & 1.95 \\
\hline Arginne & 0.79 & 1.37 & 1.83 & 2.05 \\
\hline Proline & 3.80 & 12.96 & 1.56 & 6.23 \\
\hline Histidine & 0.00 & 1.12 & 1.65 & 1.75 \\
\hline Aspartate & 4.36 & 1.78 & 2.96 & 3.08 \\
\hline Lysine & 4.46 & 3.20 & 6.20 & 5.99 \\
\hline Methionine & 2.67 & 3.15 & 2.80 & 3.67 \\
\hline Threonine & 2.85 & 2.10 & 7.42 & 5.05 \\
\hline Isoleucine & 5.71 & 9.08 & 9.17 & 6.12 \\
\hline Tyrosine & 1.23 & 1.12 & 1.05 & 1.45 \\
\hline Phenylalanine & 5.88 & 3.70 & 5.54 & 6.02 \\
\hline Leucine & 5.98 & 3.53 & 7.60 & 6.86 \\
\hline Valine & 3.09 & 2.90 & 2.56 & 3.10 \\
\hline Alanine & 7.67 & 7.20 & 0.57 & 6.90 \\
\hline Cycteine & 3.98 & 2.91 & 3.74 & 3.80 \\
\hline Serine & 0.00 & 0.00 & 0.00 & 0.00 \\
\hline Glycine & 0.00 & 0.00 & 0.00 & 0.00 \\
\hline Totals & 54.85 & 57.77 & 55.20 & 64.02 \\
\hline
\end{tabular}

The values are average of both seasons (2017 and 2018) 
Histological characters:

Leaf anatomy

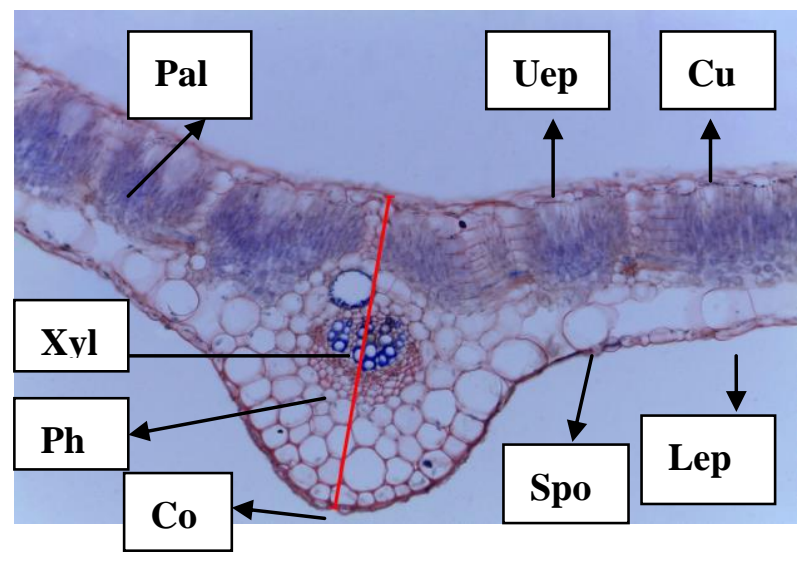

A

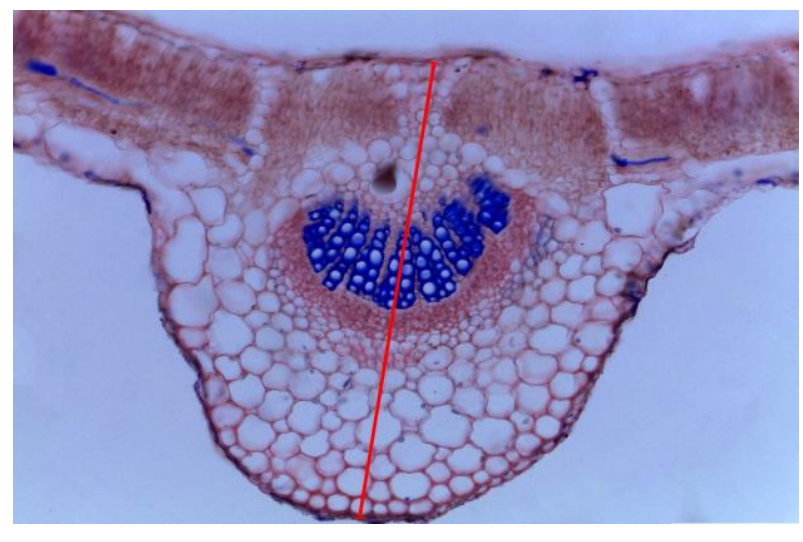

B

A) Control

B) combined treatment plants (100x)

Uep: upper epidermis, Co: collenchyma, Xyl: xylem, Cu: cuticle, Spo: spongy mesophyll

Lep: lower epidermis, Ph: Phloem, Pal: palisade mesophyll

Table (10) Histological characters of peanut leaf treated with volcanic ash plus magnetite mineral and control

\begin{tabular}{l|l|l}
\hline treats & Control A & Combined treatment B \\
$\begin{array}{l}\text { characters } \\
{[\mu \mathrm{m}]}\end{array}$ & & \\
\hline Thick. of upe.epi $[\mu \mathrm{m}]$ & 15 & 20 \\
\hline Thick. of lower.epi $\backslash[\mu \mathrm{m}]$ & 10 & 10 \\
\hline Thick. of palisade $\backslash[\mu \mathrm{m}]$ & 90 & 140 \\
\hline Thick. of spongy $[\mu \mathrm{m}]$ & 55 & 60 \\
\hline Thick. of midrib $[\mu \mathrm{m}]$ & 510 & 790 \\
\hline Thick. of xylem\ $[\mu \mathrm{m}]$ & 80 & 130 \\
\hline Thick. of phloem $[\mu \mathrm{m}]$ & 30 & 40 \\
\hline
\end{tabular}

It's obvious from data in Table (10) that histological characters for leaf of peanut exhibited that plants treated with combined treatment (volcanic ash plus magnetite mineral) showed the high value for most characters where, thickness of upper epidermis for combined plants showed an increase by $33.3 \%$ over the control, where thickness of lower epidermis was equal than control .On the other hand thickness of palisade recorded the highest value over the control by $55.5 \%$ for this trait, also the same trend was verified for trait thickness of spongy which recorded $9.1 \%$ over the control. Vascular bundle of leaf exhibited the highest increase over the control especially for thickness of xylem, which recorded $62.5 \%$ over the control whereas for thickness of phloem recorded $33.3 \%$ over the control also. Thickness of midrib keep the same trend for increasing like most characters which recorded an increase by $51.6 \%$ over the control. Hence it was concluded that as data mentioned before mixed treatment significantly improved leaf anatomy characters which recorded the highest value over the 
control, and that found logic where improving of vascular tissues is obvious for that could reverse upon improvement translocation of nutrients from soil and the photosynthates from leaves to different plant parts (Marschner 1995). Besides added volcanic ash plus magnetite mineral maybe reflect the well-built growth leaf tissue which means healthier comparing with tissue of control plants. Variation of leaves tissues between mixed treatment and control maybe also due to interaction of endogenous phytohormones which caused changes in tissues development and morphogenesis (Youssef and Abd El-Aal 2013). Present results were derived from chlorophyll concentration that was higher in combined treatment (volcanic ash plus magnetite mineral) leaves compared to control.

\section{* Economical evaluation}

Economical evaluation was done to answer the question could magnetite mineral and volcanic ash as (multi-nutrient silicate rock fertilizers) substitute NPK as traditional fertilizer. Data in Table (10) clearly reported that combine volcanic ash with magnetite mineral gave the maximum net profit compared to control treatment. The very considerable drop in the price tag of production/ hectare over control for combine volcanic ash with magnetite mineral is economically acceptable visible of the upper price of the yield obtained from this treatment. In addition, the same trend for volcanic ash or magnetite mineral treatment was observed but less economically visible than the combine volcanic ash with magnetite mineral.

Table (11). Costs and profit for volcanic ash and magnetite mineral application

\begin{tabular}{|c|c|c|c|c|c|c|c|c|c|}
\hline $\begin{array}{l}\text { Price of } \\
\text { chemical } \\
\text { fertilizers(L.E.) }\end{array}$ & $\begin{array}{l}\text { Price of } \\
\text { volcanic } \\
\text { ash } \\
\text { (L.E.) }\end{array}$ & $\begin{array}{l}\text { Price of } \\
\text { magnetite } \\
\text { mineral } \\
\text { (L.E.) }\end{array}$ & $\begin{array}{l}\text { Price of } \\
\text { volcanic } \\
\text { ash }+ \\
\text { magnetite } \\
\text { mineral } \\
\text { (L.E.) }\end{array}$ & $\begin{array}{l}\text { Price of } \\
\text { compost } \\
\text { (L.E.) }\end{array}$ & $\begin{array}{l}\text { Labor } \\
\text { cost } \\
\text { (L.E.) }\end{array}$ & $\begin{array}{l}\text { Total } \\
\text { cost } \\
\text { (L.E.) }\end{array}$ & $\begin{array}{l}\text { Increase } \\
\text { in yield } \\
\text { over } \\
\text { control } \\
\text { per } \\
\text { hectare } \\
(\mathrm{Kg}) \\
\end{array}$ & $\begin{array}{l}\text { Price of } \\
\text { increase in } \\
\text { yield over } \\
\text { control } \\
\text { (L.E.) }\end{array}$ & $\begin{array}{l}\text { The } \\
\text { net } \\
\text { profit } \\
\text { (L.E.) }\end{array}$ \\
\hline 2800 & 900 & 460 & 1360 & 3105 & 3450 & 7915 & 5681 & 113620 & 6550 \\
\hline
\end{tabular}

It could be concluded that one of the chief intentions for agricultural strategy is raising the productivity of sandy soils. The employ of volcanic ash (multi-nutrient silicate rock fertilizers) and magnetite mineral (low-cost locally available geological nutrient resources) for agricultural expansion especially in new reclaimed soil are very important. Entire rock silicate fertilizers categories have the possible to deliver soils with a large selection of macro and micronutrients in contrast to traditionally available soluble fertilizers. Soil chemical and physical properties, are candidly affected by volcanic ash and magnetite mineral alone or mixture. Moreover, vegetative parameters of the crop as well as it seed yield was profitably boosted with soil volcanic ash and magnetite mineral. The highest values of $\mathrm{N}, \mathrm{P}, \mathrm{K}$, and micronutrients uptake by hay and seeds were gained by volcanic ash and magnetite mineral. Oil content, protein and carbohydrate percent in peanut seeds were certainly manipulated by all treatments compared with the NPK control treatment. The highest value of agronomic efficiency was get hold of all practical treatments and it could arrangement in descending order of volcanic ash plus magnetite mineral > volcanic ash > magnetite mineral > control 


\section{References}

Abd-El-Latif, T. (2006). Effect of Chemical, Organic Fertilizers and Spraying with Active Dry Yeast on Growth, Oil Production and Plant Constituents of Sage (Salvia officinalis, L.) Plant. M.Sc. Thesis, Fac. Agric., Cairo Univ., Egypt. 136.

Abdul, Q. A. M. S., \& Hozayn, M. (2010). Response of growth, yield, yield components and some chemical constituents of Flax for irrigation with magnetized and tap water. World Applied Science Journal, 8(5), 630-634.

Abou El-Yazied, A., El-Gizawy, A. M., Khalf, S. M., El-Satar, A., \& Shalaby, O. A. (2012). Effect of Magnetic Field Treatments for Seeds and Irrigation Water as Well as N, P and K Levels on Productivity of Tomato Plants. Journal of Applied Sciences Research, 8(4), 2088-2099.

Abou-el-Seoud, I. I., \& Abdel-Megeed, A. (2012). Impact of rock materials and biofertilizations on $\mathrm{P}$ and $\mathrm{K}$ availability for maize (Zea maize) under calcareous soil conditions. Saudi J. Biol. Sci., 19, 55-63. https://doi.org/10.1016/j.sjbs.2011.09.001

Aladjadjiyan, A. (2010). Influence of stationary magnetic field on lentil seeds. Int. Agro. phys., 24, 321-324.

Alikamanoglu, S., \& Sen, A. (2011). Stimulation of growth and some biochemical parameters by magnetic field in wheat (Triticum aestivum L.) tissue cultures. African Journal of Biotechnology, 10(53), 10957-10963. https://doi.org/10.5897/AJB11.1479

Amber, H., Arvind, K., Promod, K., \& Zafar, A. (2008). Effect of nitrogen levels on growth herb yield and essential oil content of Ocimum basilicum var. Gabratum (sweet basil). India. J. Tropical Biodiversity, 15(2), 140-143.

Bartels, D., \& Sunkar, R. (2005). Drought and salt tolerance in plants. Crit. Rev. Plant Sci., 24, 23-58. https://doi.org/10.1080/07352680590910410

Bernardi, A. C., Werneck, C. G., Gesualdihaim, P., Rezende, N. G. A., Paiva, P. R. P., \& Monte, M. B. M. (2008). Growth and mineral nutrition of Rangpur Lime rootstock cultivated in substrate with zeolite enriched with NPK. Revista Brasileira de Fruticultura, 30(3), 794-800. https://doi.org/10.1590/S0100-29452008000300039

Chien, S. H., \& Menon, R. G. (1995). Factors affecting the agronomic effectiveness of phosphate rock for direct application. Fert Res., 41, 227-234.

https://doi.org/10.1007/BF00748312

Das, D. K. (2007). In: Micronutrients: Their Behavior in Soils and Plants. Second revised Ed., Kalyani Publishers, Ludhiana/New Delhi.

De Leenheer, L., \& Boodt, M. De (1965). Soil Physics. International Training Center for Post Graduate Soil Scientists, Ghost.

Dexter, A. R. (2004). Soil physical quality. Part I: Theory, effects of soil texture, density, and organic matter, and effects on root growth. Geoderma, 120, 201-214. 
https://doi.org/10.1016/j.geoderma.2003.09.004

Esitken, A., \& Turan, M. (2004). Alternating magnetic field effects on yield and plant nutrient element composition of strawberry (Fragaria X Ananassa cv. camarosa). Acta Agriculturae Scandinavica, Section B- Plant Soil Science, 52(3), 135-139.

https://doi.org/10.1080/09064710310019748

Ewing, S. A., \& Singer, M. J. (2012). Soil quality. In P. M. Huang, Y. Li, \& M. E. Sumner (Eds.), Handbook of soil sciences: Resource management and environmental impacts (2nd ed., p. 26). Boca Raton: CRC Press.

FAO (2000). Fertilizers and their use. $4^{\text {th }}$ edition: handbook was prepared originally for use by extension officers working for the FAO Fertilizer Programme. Rome : FAO, 34.

Fyfe, W. S., Kronberg, B. I., Leonardos, O. H., \& Olorufemi, N. (1983). Global tectonics and agriculture: a geochemical perspective. Agr. Ecosyst. Env. 9,

383-399. https://doi.org/10.1016/0167-8809(83)90023-3

Gayathiri, M., \& Anburani, A. (2008). Influence of organic and inorganic nutrients on yield in kacholam (Kaempferia galangal L.). Advances in Plant Sciences, 21(2), 453-455.

Gholizadeh, A., Esfehani, M., Azizi, M., \& Inanlou, M. (2006). The study on the effect of different levels of zeolit and water stress on growth, development and essential oils content of Moldavian balm. Agricultural Sciences and Technology, 20(2), 113-121.

Harley, A. D., \& Gilkes, R. J. (2000). Factors influencing the release of plant nutrient elements from silicate rock powders: a geochemical overview. Nutr Cycl Agroecosyst, 56, 11-36. https://doi.org/10.1023/A:1009859309453

Hassan, A. Z. A., \& Abd El-Wahab, M. M. (2012). The combined effect of bentonite and natural zeolite on sandy soil properties and productivity of some crops. Egypt. J. of Appl. Sci., 27(11), 825-838.

Helrich, K. (1990). Official methods of analysis, 15th ed. Arlington, USA: Association of Official Agricultural Chemist., 1, 673

Iskander, A. L., Khald, E. M., \& Sheta, A. S. (2011).Zinc and manganese sorption behavior by natural zeolite and bentonite. J. Biol. Sci. 19, 55-63.

https://doi.org/10.21608/ajs.2011.14686

Jackson, M. L. (1973). Soil Chemical Analysis. New Delhi : Printice-Hall of India. Privat Limited, New Delhi. Text book. pp. 144-197, 381.

Kinsella, J., Shimp, J., Mai, J., \& Weihrauch, J. (1977). Fatty acid content and composition of freshwater finfish. J. Am. Oil Chem. Soc., 54, 424-429. https://doi.org/10.1007/BF02671025

Klute, A. (1986). Laboratory measurement of hydraulic conductivity of saturated soil. In "Methods of Soil Analysis", C.A. Black et al., Part I, pp 210-221, Am. Soc. Agron. Inc. Publisher, Madison. 
Lawlor, D. W. (2002). Limitation to photosynthesis in water-stressed leaves: stomata vs. metabolism and the role of ATP. Annals of Botany 89, 871-885.

https://doi.org/10.1093/aob/mcf110

Leonardosoh, F. W. S., \& Kronbergbi. (1987).The use of ground rocks in laterite systems: an improvement to the use of conventional soluble fertilizers? Chem Geol, 60, 361-370. https://doi.org/10.1016/0009-2541(87)90143-4

Marschner, H. (1995). Functions of Mineral Nutrients: Micronutrients. In: Mineral Nutrition of Higher Plants, 2nd Edition, Academic Press, London, 313-404.

https://doi.org/10.1016/B978-012473542-2/50011-0

Mostafzadeh, F. B., Khoshraresh, M., Mousavi, S., \& Kiani, A. (2011). Effects of magnetized water on soil sulphate ions in trickle irrigation.2nd International conference on Environmental Engineering and Application, IPCBEE, 17 (C) (2011) IACST press, Singapore.

Mubashir, M., Malik, S. A., Khan, A. A., Ansari, T. M., Wright, S., Brown, M. V., \& Islam, K. R. (2010). Growth, yield and nitrate accumulation of irrigated carrot and okra in response to nitrogen fertilization. In Pakistan Journal of Botany, 42(4), 2513-2521.

Nassar, M. A., \& El-Sahhar, K. F. (1998). Botanical Preparations and Microscopy (Microtechnique). Academic Bookshop, Dokki, Giza, Egypt, 219 pp. (In Arabic).

Page, A. I., Miller, R. H., \& Keeney, D. R. (1982). Methods of Soil Analysis. Part 2: Chemical and Microbiological Properties. 2 Edition, Amer. Soc. of Agron., Madison, Wiscosin, U.S.A.

Radhakrishnan, R., \& Kumari, B. D. R. (2012). Pulsed magnetic field: Acontemporary approach offers to enhance plant growth and yield of soybean. Plant Physiology and Biochemistry, 51, 139-144. https://doi.org/10.1016/j.plaphy.2011.10.017

Sarwar, G., Hussain, N., Schmeisky, H., Muhammad, S., Ibrahim, M., \& Safdar, E. (2007). Use of compost an environment friendly technology for enhancing rice-wheat production in Pakistan. In Pakistan Journal of Botany, vol. 39, no. 5, pp.1553-1558.

Sathya, S., Mahendran, P. P., \& Arulmozhiselvan, K. (2013). Availability of nutrients as influenced by boron application in boron deficient soil of Typic Haplustalf, Agricultural Science Digest, 33, 317-320. https://doi.org/10.5958/j.0976-0547.33.4.033

Shabrangi, A., Majd, A., \& Sheidai, M. (2011). Effects of extremely low frequency electromagnetic fields on growth, cytogenetic, protein content and antioxidant system of Zea mays L. African Journal of Biotechnology, 10(46), 9362-9369.

https://doi.org/10.5897/AJB11.097

Stewart, D. W., \& Shamdasani, P. N. (1990). Focus Groups: Theory and Practice. Sage, Newbury Park, CA.

Van Straaten, P. (2007) Agrogeology: The use of rocks for crops. Enviro. quest Ltd., Canada, $440 \mathrm{p}$. 


\section{Macrothink}

Willey, R. L. (1971). Microtechniques: A Laboratory Guid. Macmillan Publishing Co., Inc., New York., pp.99.

Wu, D. X., Wang, G. X., Bai, Y. F., \& Liao, J. X. (2004). Effects of elevated $\mathrm{CO} 2$ concentration on growth, water use, yield and grain quality of wheat under two soil water levels, Agriculture, Ecosystems and Environment, 104, 493-507. https://doi.org/10.1016/j.agee.2004.01.018

Young, C. T., Waller, G. R., Matlock, R. S., Morrison, R. D., \& Hammons, R. O. (1974). Some environmental factors affecting free amino acid composition in six varieties of peanuts. J. Am. Oil Chem. SOC., 51, 265-268. https://doi.org/10.1007/BF02642633

Youssef, A. S. M., \& Abd El-Aal, M. M. M. (2013). Effect of paclobutrazol and cycocel on growth, flowering, chemical composition and histological features of potted Tabernaemontana coronaria Stapf plant. J. Appl. Sci. Res., 9(11), 5953-5963.

Zainudin, S. R., Muyang, K., Mustafa, K., \& Ismawi, Z. (2010). Photosynthetic and stomatal responses of J. Curcas to different watering regimes. Proceedings of the 11th Symposium for the Malaysian Society of Applied Biology, 406-413.

Zepeda, R. B., Hernandez, C. A., Suazo, F. L., Dominguez, A. P., Cruz, A. O., Martinez, E. O., \& Hernandez, L. M. S. (2011). Physical characteristics of maize grains and tortilla exposed to electromagnetic field. Int. Agrophys., 25, 389-393.

\section{Copyright Disclaimer}

Copyright for this article is retained by the author(s), with first publication rights granted to the journal.

This is an open-access article distributed under the terms and conditions of the Creative Commons Attribution license (http://creativecommons.org/licenses/by/4.0/). 